\title{
Functioning of the geo-ecosystem of a river basin
}

\author{
ELENA ASABINA
}

Ugra State University, 16, Chekhov str., 628012 Khanty-Mansiysk, Russia easabina@list.ru

Only a certain quantity of water resources are formed in a river basin. This quantity is defined by the climatic zone, by natural zone and by existing landscapes. The knowledge of the functioning of river runoff in a river basin will allow consideration of the natural interdependence between the annual runoff renewal and the available environment (Asabina 2008).

The studied basins are located on the eastern slope (the Amur River) and the western slope (the Seine River) of the Eurasian continent (Fig. 1). The total area is $1.9336 \times 10^{6} \mathrm{~km}^{2}$. Runoff parameters reflect the total result of the functioning of the geo-ecosystem of a river basin. At the mouth of the Amur River, the normal annual specific discharge is $6.9 \mathrm{~L} /\left(\mathrm{s} \times \mathrm{km}^{2}\right)$, that is $12800 \mathrm{~m}^{3} / \mathrm{s}$. At the mouth of the Seine, the normal annual specific discharge is $6.4 \mathrm{~L} /\left(\mathrm{s} \times \mathrm{km}^{2}\right)$, that is $500 \mathrm{~m}^{3} / \mathrm{s}$. Thus, these rivers have similar values of normal annual specific discharges $(6.9$ and $\left.6.4 \mathrm{~L} /\left(\mathrm{s} \times \mathrm{km}^{2}\right)\right)$, despite their remoteness from each other. There are some reasons for the identical hydrological result.

Position and hydrography, as geo-ecosystem components, have an influence on the basin runoff. First, the area of the Seine River basin is 24 times smaller than the area of the Amur River basin. Therefore, the real volume of precipitation, which has fallen within the basins differs. Secondly, the length of the Seine River is 3.6 times shorter than the length of the Amur River. As a result, water of the Seine River flows down more quickly to the ocean. However, there are regular fluctuations of water level at the river mouths because of tides. The runoff of these rivers flow directly into the ocean. At their mouths, the tidal amplitude is 7.0-7.5 m for the Seine River and 1.5-2.0 $\mathrm{m}$ for the Amur River (Geographical encyclopedia 2003). Consequently, the water flows with a delay into the ocean due to the backwater.

Precipitation and evaporation, as geo-ecosystem components, also have an influence on the runoff. The Amur and Seine river basins have identical temperate climates (Geographical encyclopedia 2003). In the Seine River basin, the annual quantity of precipitation is 3.0-1.2 times more than in the Amur River basin (Fig. 1). However, the value of evaporation is 2.1-1.4 times more also in the Seine River basin. There is no evaporation from the Amur River basin surface for 7 months because of the low air temperatures.

In addition, the natural zone of the basins are both forest zone. Coniferous forest prevails in the Amur River basin, and deciduous forest in the Seine River basin. The forest reduces the values of overland runoff through the capture of liquid precipitation by the crown, through the reduction of overland runoff speed by forest litter, and through the decrease of evaporation from soil.

Also, the feeding of the rivers is identical for the Amur and the Seine river basins. It is seasonal monsoonal rain. The rain runoff is $75-80 \%$ of annual runoff. The large wave of maximal runoff is formed within July-September (4 months for the Amur River) and November-March (6 months for the Seine River).

For the Amur River there is a long period when only the groundwater feeds runoff because of the ice phenomena. The ice cover is lasts 5-6 months (November-April). The Seine River has no regular ice phenomena, and consequently, rains feed this river within all year.

The similar values of the normal annual specific discharges testify to the effect that the total influence of the geo-ecosystem is analogous. As a result, the values of steady runoff renewal are also analogous for the Amur and the Seine river basins. Another hydrological parameter confirms this result, i.e. the surplus and deficit of river water resources in river basin. This hydrological 


\section{POSITION AND HYDROGRAPHY}

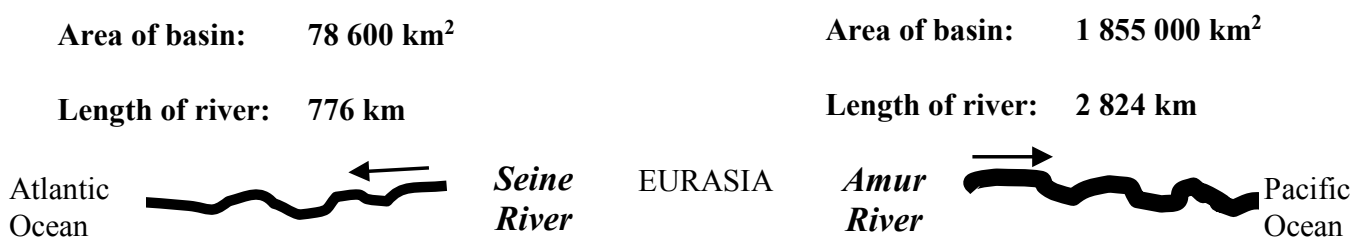

CLIMATE AND NATURAL ZONE

Temperate climate

Deciduous forest

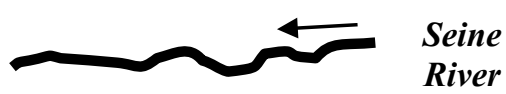

EURASIA

Temperate climate

Coniferous forest

ANNUAL PRECIPITATION AND EVAPORATION, mm

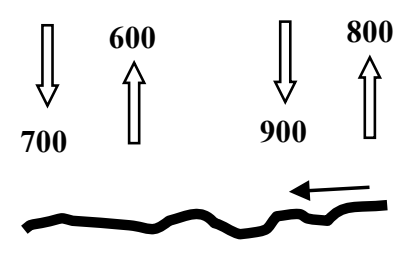

Seine
River

EURASIA

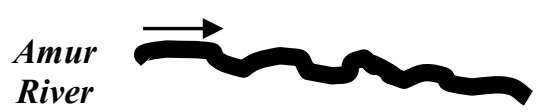

HYDROLOGICAL PARAMETERS

Annual specific discharge: $6.4 \mathrm{~L} /\left(\mathrm{s} \times \mathrm{km}^{2}\right)$

Discharger: $\quad 500 \mathrm{~m}^{3} / \mathrm{s}$

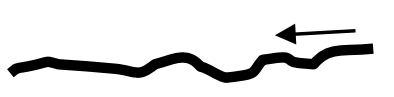

Annual specific discharge: $6.9 \mathrm{~L} /\left({\left.\mathrm{s} \times \mathrm{km}^{2}\right)}^{2}\right.$

Discharger: $\quad 12800 \mathrm{~m}^{3} / \mathrm{s}$

EURASIA

Amur

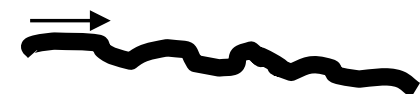

Fig. 1 Geo-ecosystem components

parameter was mapped long ago (World Water Balance and Water Resources of the Earth 1974). The surplus of river water resources is $200 \mathrm{~mm}$, both for the Amur River basin and for the Seine River basin.

There are many such river basins with identical hydrological results in each climate. The runoff "develops" itself a channel to provide a passage for the total volume of water. Extreme phenomena of this natural process are canyons and waterfalls. The functioning of the geoecosystem in each river basin is a separate component of the global geo-ecosystem, which provides the stable global transfer of water, of chemical substances and of energy.

\section{REFERENCES}

Asabina, E. (2008) Sustainable water management by maintenance of the natural environment in river basins. In: Tchiguirinskaia, I, Demuth, S. and Hubert, P. (ed) River Basins - From Hydrological Science to Water Management. IAHS Press, Wallingford, UK: IAHS Publ. 323, 87-92.

Geographical encyclopedia (2003) The scientific edition "Greater Russian encyclopedia”. Moscow, Russia (in Russian). World Water Balance and Water Resources of the Earth (1974) Gidrometeoizdat, Leningrad, Russia (in Russian). 